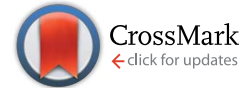

Cite this: J. Mater. Chem. A, 2014, 2 , 15008

Received 23rd April 2014

Accepted 21st July 2014

DOI: $10.1039 / c 4 t a 02031 f$

www.rsc.org/MaterialsA

\section{Spray-deposited zinc titanate films obtained via sol-gel synthesis for application in dye-sensitized solar cells $\dagger$}

\author{
Kuhu Sarkar, ${ }^{a}$ Erik V. Braden, ${ }^{a}$ Thomas Fröschl, ${ }^{b}$ Nicola Hüsing ${ }^{b}$ \\ and Peter Müller-Buschbaum ${ }^{\star a c}$
}

Foam-like zinc orthotitanate $\left(\mathrm{Zn}_{2} \mathrm{TiO}_{4}\right)$ is successfully synthesized via the wet chemical sol-gel route assisted with a structure-directing diblock copolymer template. The wet chemical route enables spray deposition of $\mathrm{Zn}_{2} \mathrm{TiO}_{4}$ films. Calcination temperature of the spray-deposited films is shown to be crucial for the synthesis of the compound phase, $\mathrm{Zn}_{2} \mathrm{TiO}_{4}$. Surface composition and optical properties of the films are also studied. Finally, $\mathrm{Zn}_{2} \mathrm{TiO}_{4}$ films are shown to offer a reasonable functioning as an electron acceptor in dye-sensitized solar cells, with the best preliminary performance reported so far.

\section{Introduction}

Evolution of highly ordered inorganic metal oxide nanostructures has gained substantial momentum in recent years, owing to their extraordinary structural and electronic properties. The tremendous increase in the demand for nanoscale electronic devices ${ }^{\mathbf{1 , 2}}$ has motivated researchers to produce complex functional nanomaterials consisting of binary and/or ternary composites in addition to pure phases. In the present investigation, we focus on the synthesis of a ternary compound, namely, zinc orthotitanate in a solution-based sol-gel approach. As reported in literature, the simultaneous synthesis of $\mathrm{TiO}_{2}-\mathrm{ZnO}$ nanocomposites gives rise to three different compounds and some minor impurities. These three compounds are: zinc orthotitanate $\left(\mathrm{Zn}_{2} \mathrm{TiO}_{4}\right)$ with a cubic spinel structure, $\mathrm{Zn}_{2} \mathrm{Ti}_{3} \mathrm{O}_{8}$ with a cubic defect spinel structure and zinc metatitanate $\left(\mathrm{ZnTiO}_{3}\right)$ with a rhombohedral ilmenite structure. The minor impurity phases consist of rutile $\mathrm{TiO}_{2}$ or $\mathrm{ZnO} . \mathrm{Zn}_{2} \mathrm{Ti}_{3} \mathrm{O}_{8}$ is a metastable form of $\mathrm{ZnTiO}_{3}$ and is known to occur at temperatures lower than $800{ }^{\circ} \mathrm{C}$, whereas, $\mathrm{ZnTiO}_{3}$ is well-known to decompose to $\mathrm{Zn}_{2} \mathrm{TiO}_{4}$ and rutile $\mathrm{TiO}_{2}$ at temperatures above $945{ }^{\circ} \mathrm{C} .{ }^{3}$ Hence, the production of a pure composite is a challenge resulting from the temperature requirements for the synthesis of a particular compound.

${ }^{a}$ Technische Universität München, Physik-Department, Lehrstuhl für Funktionelle Materialien, James-Franck-Straße 1, 85748 Garching, Germany. E-mail: muellerb@ ph.tum.de; Fax: +49-89-289-12473; Tel: +49-89-289-12451

${ }^{b}$ Materialchemie, FB Materialforschung und Physik, Universität Salzburg, Hellbrunnerstraße 34, 5020 Salzburg, Austria. E-mail: nicola.huesing@sbg.ac.at; Tel: $+43-662-8044-5404$

${ }^{c}$ Nanosystems Initiative Munich, Schellingstraße 4, 80799 München, Germany

$\dagger$ Electronic supplementary information (ESI) available. See DOI: $10.1039 / \mathrm{c} 4 \mathrm{ta02031f}$
Among the three reported common compounds, $\mathrm{Zn}_{2} \mathrm{TiO}_{4}$ is the center of interest in the present work due to its high potential for several applications. $\mathrm{Zn}_{2} \mathrm{TiO}_{4}$ has been established as one of the most important regenerable photocatalysts, additionally showing wide-scale applications in the removal of sulfur during coal gasification, ${ }^{3}$ photocatalytic splitting of water and degradation of organic compounds, as an active anode material in Li-ion batteries, microwave dielectrics, pigments and many more. ${ }^{4}$ A major field of application, where inorganic metal oxides have largely contributed, is in energy conversion and storage. In particular, dye-sensitized solar cells (DSSCs) is one of the most successful technologies for the conversion of solar energy into electricity. ${ }^{5,6}$ Conventionally, $\mathrm{TiO}_{2}$ has been used for DSSCs, ${ }^{7}$ however, more recent studies have shown promising results for ZnO-based DSSCs as well. ${ }^{8}$ In addition, several attempts have been made in order to combine these two materials together to harvest their synergetic structural and electronic properties. ${ }^{8-10}$ These initiatives have inspired us to prove the competence of the titania $\left(\mathrm{TiO}_{2}\right)$-zinc oxide $(\mathrm{ZnO})$ compound, $\mathrm{Zn}_{2} \mathrm{TiO}_{4}$ in the field of DSSCs. The present article is focused on the synthesis procedure to obtain a pure compound phase of $\mathrm{Zn}_{2} \mathrm{TiO}_{4}$ via a wet chemical route and its characterization rather than device optimization. Nevertheless, to our knowledge, this is the first contribution so far, reporting a reasonable device efficiency using $\mathrm{Zn}_{2} \mathrm{TiO}_{4}$.

The most common technique to synthesize $\mathrm{Zn}_{2} \mathrm{TiO}_{4}$ is the direct solid-state route employing a high temperature of $1000{ }^{\circ} \mathrm{C} .{ }^{3}$ Other methods producing pure and mixed phases of $\mathrm{Zn}_{2} \mathrm{TiO}_{4}$ involve metal-organic chemical vapor deposition, ${ }^{\mathbf{1 1}}$ ball milling, ${ }^{12,13}$ sol-electrospinning ${ }^{\mathbf{1 4}}$ and synthesis using inorganic metal oxide templates via sputtering. ${ }^{15}$ Although a few morphologies of the compound are proclaimed, such as nanorods, twinned nanowires, ${ }^{15}$ fibres ${ }^{14,16}$ and nanocrystalline powders, ${ }^{17}$ a thorough investigation about the possible 
nanomorphologies is still lacking, which is crucial for final device applications. Moreover, all the above-mentioned synthesis routes suffer the common disadvantage of nontunability of length scale of the nanostructures obtained.

In the present work, we use a diblock copolymer templateassisted sol-gel technique to produce $\mathrm{Zn}_{2} \mathrm{TiO}_{4}$ nanostructures. This technique has been already well-established for structuring inorganic metal oxides such as $\mathrm{TiO}_{2}$ (ref. 18) and $\mathrm{ZnO}^{19}$ The major advantages provided by this approach involve the ability to obtain multiple morphologies using the same copolymer template and the flexibility to tune the length scales of the nanostructures at the same time for a specific need. Moreover, being a solution-based procedure, sol-gel synthesis allows for different deposition methods that can be applied in order to obtain thin films. This is particularly beneficial for fabrication of solar cells, where large-scale techniques such as printing, slot-die coating or spraying can be employed for solutions. Furthermore, different methods of deposition of the solution subject the films to different drying times, which in turn provide additional tuneability to the final length scales evolved in the films.

Fig. 1 shows a schematic representation of the multi-step process involved in producing $\mathrm{Zn}_{2} \mathrm{TiO}_{4}$ nanostructures via a template-assisted sol-gel route. The preparation routine begins with two sols obtained individually for $\mathrm{ZnO}$ and $\mathrm{TiO}_{2}$. This is represented in Fig. 1(a) and (b), respectively. For both cases, a required amount of the amphiphilic diblock copolymer,

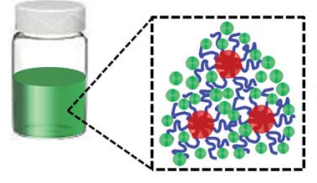

(a) $\mathrm{ZnO}$ sol

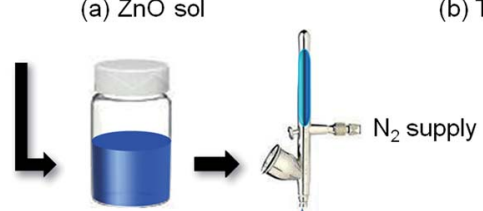

(b) $\mathrm{TiO}_{2} \mathrm{sol}$

(e) spray-deposited hybrid film

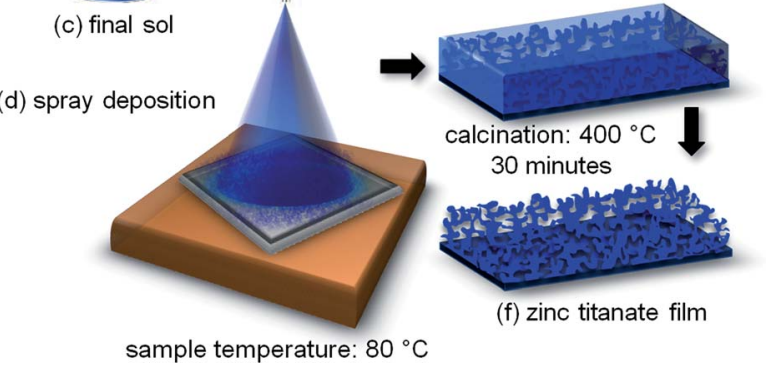

Fig. 1 A schematic illustration of the steps involved in the synthesis of a nanostructured zinc titanate film via sol-gel route using $P(S-b-E O)$ as the structure-directing template. (a) Preparation of zinc oxide sol using zinc acetate dihydrate as the precursor. (b) Preparation of titania sol using ethylene glycol-modified titanate as the precursor. (c) Mixing the two sols together in the required volume ratio to obtain the final zinc titanate sol. (d) Spray deposition of zinc titanate sol using nitrogen as the carrier gas on a heated substrate. (e) Spray-deposited zinc titanate hybrid film. (f) Final calcination step to remove the polymer template yielding pure zinc orthotitanate nanostructured film. poly(styrene-block-ethylene oxide), $\mathrm{P}(\mathrm{S}-b$-EO) is dissolved in a solvent pair, one with good and the other with weak interactions with the blocks, in order to induce micro-phase separation leading to formation of micelles. The micelles in the solution are represented with red hydrophobic (PS) core and blue hydrophilic (PEO) corona in the insets of Fig. 1(a) and (b). The respective metal oxide precursors are then added to the individual solutions (depicted as green spheres for the $\mathrm{ZnO}$ sol and gray spheres for $\mathrm{TiO}_{2}$ sol), which selectively get incorporated in the hydrophilic part of the template and thereby react in a limited volume to initiate the formation of nanostructures in the system. In this fashion, the morphologies to be produced in the end are controlled and tuned as a function of the weight fraction of the solvents and the precursors added to the system. Finally, the two sols are mixed with a specific volume ratio to obtain a final sol as indicated in Fig. 1(c), which controls the morphology in the final system. To realize practical applications, the nanostructures are deposited in the form of solid films on the substrate by the spraying technique as shown in Fig. 1(d). Spray deposition is an industry-oriented approach towards preparation of films with an easy upscaling of the film thicknesses and final production volume. ${ }^{20}$ Combinations of different volumes of the $\mathrm{ZnO}$ and the $\mathrm{TiO}_{2}$ sols are sprayed in this study and are noted in Section S1 of the ESI $\dagger$ along with details about the spray protocol. In the course of this synthesis routine, it has been shown that the mixing ratio plays a crucial role to obtain the pure $\mathrm{Zn}_{2} \mathrm{TiO}_{4}$ phase which can only be synthesized in a narrow mixing regime for $\mathrm{ZnO}$ and $\mathrm{TiO}_{2}$ precursor concentrations (see Section S1 and S2 $\dagger$ ). After the spray deposition of the films, a final calcination step is required to impart crystallinity to the system. These steps are sketched in Fig. 1(e) and (f) (the SEM images of the calcined films produced from sols containing varied molar concentrations of the $\mathrm{ZnO}$ and the $\mathrm{TiO}_{2}$ precursors are given in Section $\mathrm{S} 1 \dagger$ ). Amongst the combinations of different volumes of $\mathrm{ZnO}$ and $\mathrm{TiO}_{2}$ sols, only the final sol containing molar ratio of $\mathrm{ZnO}$ precursor: $\mathrm{TiO}_{2}$ precursor of $1.05: 1$, gives the pure $\mathrm{Zn}_{2} \mathrm{TiO}_{4}$ phase as characterized in the following.

\section{Experimental section}

\section{Materials and sol preparation}

The amphiphilic diblock copolymer, poly(styrene-block-ethylene oxide), abbreviated as $\mathrm{P}\left(\mathrm{S}-b\right.$-EO) [molar masses $-23 \mathrm{~kg} \mathrm{~mol}^{-1}$ for PS block; $7 \mathrm{~kg} \mathrm{~mol}^{-1}$ for PEO block; polydispersity index - 1.07] was used as received from Polymer Source Inc., Canada. Zinc acetate dihydrate $\left[\mathrm{Zn}\left(\mathrm{CH}_{3} \mathrm{COO}\right)_{2} \cdot 2 \mathrm{H}_{2} \mathrm{O}\right] 99.999 \%$ trace metals basis, with a density of $1.84 \mathrm{~g} \mathrm{~mL}^{-1}$ was purchased from Sigma Aldrich. Ethylene glycol-modified titanate $\left[\mathrm{Ti}\left(\mathrm{O}_{2} \mathrm{C}_{2} \mathrm{H}_{4}\right)_{2}\right]$, with a density of $0.343 \mathrm{~g} \mathrm{~mL}^{-1}$ was synthesized using a procedure described in literature. ${ }^{21,22}$ As described below, two different sols, for $\mathrm{ZnO}$ and $\mathrm{TiO}_{2}$ were prepared separately containing equal volumes of $\left[\mathrm{Zn}\left(\mathrm{CH}_{3} \mathrm{COO}\right)_{2} \cdot 2 \mathrm{H}_{2} \mathrm{O}\right]$ and $\left[\mathrm{Ti}\left(\mathrm{O}_{2} \mathrm{C}_{2} \mathrm{H}_{4}\right)_{2}\right]$, respectively. In order to achieve this, a specific weight fraction combination of the good solvent, the selective solvent and the precursor was chosen in each case. For the $\mathrm{ZnO}$ sol, $\mathrm{N}, \mathrm{N}$ dimethylformamide $\left[\mathrm{C}_{3} \mathrm{H}_{7} \mathrm{NO}\right]$, with a density of $0.95 \mathrm{~g} \mathrm{~mL}^{-1}$ 
was chosen as the good solvent, hence dissolving both the blocks of the diblock copolymer template. Water (density = $0.997 \mathrm{~g} \mathrm{~mL}^{-1}$ ) on the other hand only selectively dissolved the PEO block (for $\mathrm{ZnO}$ sol $-w_{\mathrm{C}_{3} \mathrm{H}_{7} \mathrm{NO}}: w_{\mathrm{H}_{2} \mathrm{O}}: w_{\mathrm{Zn}\left(\mathrm{CH}_{3} \mathrm{COO}\right)_{2} \cdot 2 \mathrm{H}_{2} \mathrm{O}}=$ $0.92: 0.005: 0.075)$. For the $\mathrm{TiO}_{2} \mathrm{sol}, \mathrm{C}_{3} \mathrm{H}_{7} \mathrm{NO}$ was again used as the good solvent, whereas, hydrochloric acid $(37 \% \mathrm{HCl})$, with a density of $1.2 \mathrm{~g} \mathrm{~mL}^{-1}$ served as the selective solvent (for $\mathrm{TiO}_{2}$ sol $\left.-w_{\mathrm{C}_{3} \mathrm{H}_{7} \mathrm{NO}}: w_{\mathrm{HCl}}: w_{\mathrm{Ti}\left(\mathrm{O}_{2} \mathrm{C}_{2} \mathrm{H}_{4}\right)_{2}}=0.905: 0.08125: 0.01375\right)$.

\section{Detailed synthesis of the zinc orthotitanate $\left(\mathrm{Zn}_{2} \mathrm{TiO}_{4}\right)$ sol}

To synthesize the principle compound, $\mathrm{Zn}_{2} \mathrm{TiO}_{4}, \mathrm{ZnO}$ and $\mathrm{TiO}_{2}$ sols were first prepared separately. For the preparation of $10 \mathrm{~mL}$ of the final $\left(\mathrm{Zn}_{2} \mathrm{TiO}_{4}\right)$ sol, $2 \mathrm{~mL}$ of $\mathrm{ZnO}$ sol was mixed with $8 \mathrm{~mL}$ $\mathrm{TiO}_{2}$ sol.

In order to prepare the $\mathrm{ZnO}$ sol, firstly, $30 \mathrm{mg}$ of $\mathrm{P}(\mathrm{S}-b$-EO) was dissolved in $1 \mathrm{~mL}$ of $\mathrm{C}_{3} \mathrm{H}_{7} \mathrm{NO}$ by stirring at room temperature for 30 minutes. Secondly, $155 \mathrm{mg}$ of $\mathrm{Zn}\left(\mathrm{CH}_{3} \mathrm{COO}\right)_{2} \cdot 2 \mathrm{H}_{2} \mathrm{O}$ was dissolved in $1 \mathrm{~mL}$ of $\mathrm{C}_{3} \mathrm{H}_{7} \mathrm{NO}$ in a separate glass vial also by stirring at room temperature for 30 minutes. Afterwards the polymer and the precursor solutions were filtered using Teflon filters with pore size of $0.45 \mu \mathrm{m}$ into two separate glass vials, respectively. Next, $10.4 \mu \mathrm{L}$ of deionized water was added to the polymer solution which was then again allowed to stir for 30 minutes at room temperature. Finally, the polymer solution (polymer $+\mathrm{C}_{3} \mathrm{H}_{7} \mathrm{NO}+$ deionized water) and the precursor solution $\left(\mathrm{Zn}\left(\mathrm{CH}_{3} \mathrm{COO}\right)_{2} \cdot 2 \mathrm{H}_{2} \mathrm{O}+\mathrm{C}_{3} \mathrm{H}_{7} \mathrm{NO}\right)$ were mixed together with the aid of a syringe pump with a controlled mixing rate of the two solutions, as described in Section S1.1 of the ESI, $\uparrow$ in order to obtain the final $\mathrm{ZnO}$ sol.

For preparation of the $\mathrm{TiO}_{2}$ sol, $120 \mathrm{mg}$ of $\mathrm{P}(\mathrm{S}-b$-EO) was dissolved in $8 \mathrm{~mL}$ of $\mathrm{C}_{3} \mathrm{H}_{7} \mathrm{NO}$ by stirring the solution at room temperature for 30 minutes. Once a clear polymer solution was obtained, it was filtered into another glass vial using a Teflon filter (pore size $-0.45 \mu \mathrm{m}$ ). To this solution, $568.6 \mu \mathrm{L}$ of $\mathrm{HCl}$ was added drop-wise followed by $115.45 \mathrm{mg}$ of $\mathrm{Ti}\left(\mathrm{O}_{2} \mathrm{C}_{2} \mathrm{H}_{4}\right)_{2}$. The $\mathrm{TiO}_{2}$ precursor $\left(\mathrm{Ti}\left(\mathrm{O}_{2} \mathrm{C}_{2} \mathrm{H}_{4}\right)_{2}\right)$ was added within $30 \mathrm{~s}$ after the addition of $\mathrm{HCl}$ to the polymer solution. This solution was then allowed to stir for 30 minutes at room temperature at the end of which a pale yellow turbid solution was obtained. After 30 minutes, the solution was heated to $90{ }^{\circ} \mathrm{C}$ and was stirred at this high temperature for 15 minutes until a pale yellow clear solution was obtained. This was then the final $\mathrm{TiO}_{2}$ sol, which stayed clear also at room temperature.

$2 \mathrm{~mL}$ of the $\mathrm{ZnO}$ sol was then added to $8 \mathrm{~mL}$ of the $\mathrm{TiO}_{2}$ sol in a drop-wise manner (without a syringe pump) at room temperature, within 1 minute time. This solution was referred to as the final $\mathrm{Zn}_{2} \mathrm{TiO}_{4}$ sol.

\section{Thin film and device preparation}

The final zinc orthotitanate sol was then spray-deposited on a substrate at $80{ }^{\circ} \mathrm{C}$ for film preparation. The spray deposition as well as the post-treatment parameters are given in Section S1.2 of the ESI. $\dagger$

After the spray deposition, the films were sintered in a tube furnace, RETTH 230/3 provided by GERO Hochtemperaturofen $\mathrm{GmbH}$ at a heating ramp of $150{ }^{\circ} \mathrm{C} \mathrm{h}^{-1}$ to $600{ }^{\circ} \mathrm{C}$ for 30 minutes.
Only after this high temperature treatment at $600{ }^{\circ} \mathrm{C}$ of the spray-deposited film prepared using the final sol, the zinc orthotitanate $\left(\mathrm{Zn}_{2} \mathrm{TiO}_{4}\right)$ compound was formed. The calcined films were then used for the fabrication of the final dye-sensitized solar cells (DSSCs). Details about the solar cell assembly and the materials involved are given in the ESI (Section S3†).

\section{Characterization}

The scanning electron microscopy (SEM) measurements on the samples were performed using a Zeiss Gemini NVision 40 apparatus. A constant accelerating voltage of $5 \mathrm{kV}$, a working distance of $3.5 \mathrm{~mm}$ and an aperture of $10 \mu \mathrm{m}$ were maintained for all the measurements.

$\mathrm{X}$-ray diffraction measurements were performed at a Bruker D8 ADVANCE powder diffractometer. The data obtained were background subtracted using the program included in the DIFFRAC.SUITE provided by Bruker. A $2 \Theta$ range from $25-60^{\circ}$ was probed using a copper anode X-ray source with wavelength $\lambda=1.54 \AA$ operated at $40 \mathrm{kV}$ and $40 \mathrm{~mA}$. The theoretical peak positions for zinc oxide and zinc orthotitanate along with their relative intensities were obtained from Inorganic Crystal Structure Database (ICSD).

The UV/vis measurements were carried out in a Lambda $650 \mathrm{~S}$ spectroscope, which provided UV (from deuterium lamp) and visible (from halogen lamp) wavelengths covering a range from 190 to $900 \mathrm{~nm}$. The films were prepared on glass and were measured in transmission geometry. The $150 \mathrm{~mm}$ integrating sphere was used to register the scattered light from the sample before the signal was directed to the detector.

The current of the DSSC was measured for an applied voltage with a Keithly 2400 source meter in dark and under illumination. A solar simulator Solar Constant by K. H. Steuernagel Lichttechnik $\mathrm{GmbH}$ was used. The intensity was calibrated and set to $1000 \mathrm{~W} \mathrm{~m}^{-2}$ using a silicon-based calibration solar cell (WPVS Reference Solar Cell Typ RS-ID-3 by Fraunhofer ISE).

\section{Results and discussion}

\section{Film morphology}

Fig. 2(a) and (b) show SEM images of the calcined $\mathrm{Zn}_{2} \mathrm{TiO}_{4}$ nanostructures under low and high magnifications, respectively,

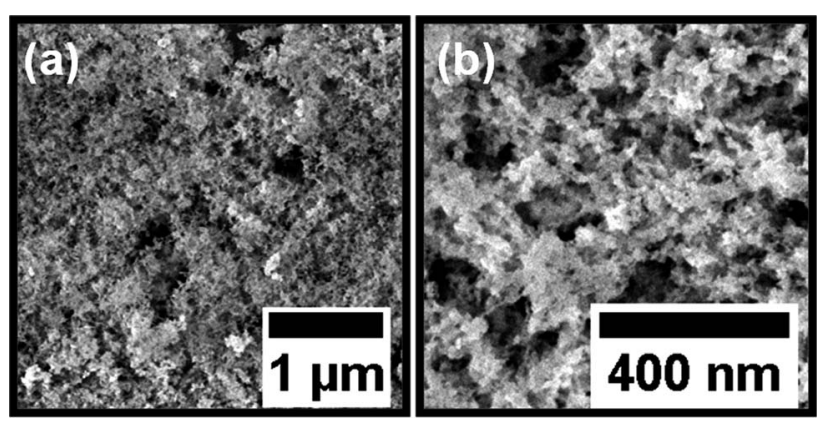

Fig. 2 Scanning electron microscopy images of the spray-deposited foam-like zinc orthotitanate film under low (a) and high (b) magnifications. 
obtained at the above-mentioned molar ratio of the $\mathrm{ZnO}$ and $\mathrm{TiO}_{2}$ precursors in the sol. Homogeneous foam-like morphology with inter-connected network is clearly observed. It has been successfully shown by Perlich $e t a l$. and Sacco et al. that spongelike network morphologies for $\mathrm{TiO}_{2}$ and $\mathrm{ZnO}$ are highly beneficial for increased surface area, leading to high dye uptake and enhanced charge transport in photovoltaic devices. ${ }^{23,24}$ In the present work, a foam-like $\mathrm{Zn}_{2} \mathrm{TiO}_{4}$ nanostructured film is successfully obtained via a wet chemical synthesis route based on a template-assisted sol-gel approach. The porosity of this foamlike $\mathrm{Zn}_{2} \mathrm{TiO}_{4}$ film is extracted from the scattering length density profile of the film in the vertical direction (see Section S2.3 of the ESI $)$ ). A promising porosity of $(52.5 \pm 4.2) \%$ is obtained for the foam-like film. The porosity of $\mathrm{Zn}_{2} \mathrm{TiO}_{4}$ film is slightly lower than that reported for pure $\mathrm{ZnO}$ foam-like films obtained from the same diblock copolymer template. ${ }^{25}$ This can be explained by the presence of two metal oxide precursors and the final composition of the sols used to prepare the film. The formation of the homogeneous foam-like morphology is also supported by the similar molar concentrations of $\mathrm{Zn}\left(\mathrm{CH}_{3} \mathrm{COO}\right)_{2} \cdot 2 \mathrm{H}_{2} \mathrm{O}$ and $\mathrm{Ti}\left(\mathrm{O}_{2} \mathrm{C}_{2} \mathrm{H}_{4}\right)_{2}$ in the respective sols. This leads to uniform mixing of the constituents resulting in the formation of a single compound phase. For dissimilar molar concentrations of $\mathrm{Zn}\left(\mathrm{CH}_{3} \mathrm{COO}\right)_{2} \cdot 2 \mathrm{H}_{2} \mathrm{O}$ and $\mathrm{Ti}\left(\mathrm{O}_{2} \mathrm{C}_{2} \mathrm{H}_{4}\right)_{2}$, final morphologies with large aggregates are produced and the formation of the desired foam-like morphology is hampered (see Section S1.3 of the ESI $\dagger$ ). Hence, the importance of the molar concentrations of the metal oxide precursors in their individual sols is crucial in order to obtain a single phase with uniform film morphology, when the sols are mixed. This promising morphology, obtained after the calcination of the sprayed film, is further characterized in order to determine its crystallinity and optical properties. The nanostructured film is finally manifested as the active layer in a functional DSSC as described in the following.

\section{Crystallinity}

Together with the composition of the sol, the impact of the calcination temperature on the formation of pure compound is also investigated. The spray-deposited film obtained from the sol containing molar concentration of $\mathrm{Zn}\left(\mathrm{CH}_{3} \mathrm{COO}\right)_{2} \cdot 2 \mathrm{H}_{2}: \mathrm{Ti}\left(\mathrm{O}_{2} \mathrm{C}_{2} \mathrm{H}_{4}\right)_{2}=1.05: 1$ is calcined at 400 and $600{ }^{\circ} \mathrm{C}$. The X-ray diffraction (XRD) spectra of these films are plotted in Fig. 3. The XRD spectra are measured over a $2 \Theta$ range of $25-60^{\circ}$. The peaks obtained show a clear signature of the presence of a pure $\mathrm{Zn}_{2} \mathrm{TiO}_{4}$ phase ${ }^{3}$ when compared to the theoretical peak positions depicted by the green vertical lines, for the film calcined at $600{ }^{\circ} \mathrm{C}$ (green curve).

The crystallite size for the film is calculated using the Scherrer's equation: ${ }^{26}$

$$
D=\frac{0.9 \lambda}{B \cos \Theta}
$$

where $\lambda$ denotes the wavelength of the X-rays, $B$ the full width at half maximum in radian and $\Theta$ the Bragg angle. The crystallite size calculated for the film calcined at $600{ }^{\circ} \mathrm{C}$, from the most intense (311) reflection is approximately $11 \mathrm{~nm}$.

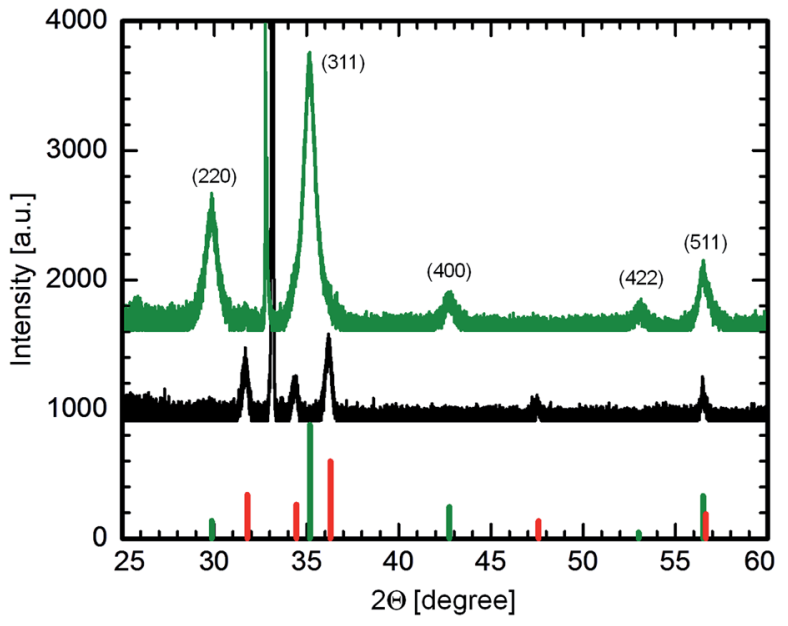

Fig. $3 \mathrm{X}$-ray diffraction spectrum of the spray-deposited films with molar concentration of $\mathrm{Zn}\left(\mathrm{CH}_{3} \mathrm{COO}\right)_{2} \cdot 2 \mathrm{H}_{2} \mathrm{O}: \mathrm{Ti}_{(}\left(\mathrm{O}_{2} \mathrm{C}_{2} \mathrm{H}_{4}\right)_{2}=1.05: 1$, calcined at $400{ }^{\circ} \mathrm{C}$ (black curve) and $600{ }^{\circ} \mathrm{C}$ (green curve). The green and the red vertical lines show the theoretical peak positions with their relative intensities for zinc orthotitanate and zinc oxide, respectively. The XRD patterns are shifted along the intensity axis for clarity. The high intensity peak observed at $2 \Theta=33^{\circ}$ in both graphs corresponds to the silicon (100) peak originating from the substrate underneath. In order to concentrate more on the peaks obtained from the films, this high intensity peak is cut off at higher intensities. The Miller indices are indicated for the zinc orthotitanate peaks, corresponding to the green curve.

On the other hand, for the diffraction spectrum of the film calcined at $400{ }^{\circ} \mathrm{C}$ (black curve in Fig. 3), there is a clear absence of any signal corresponding to the $\mathrm{Zn}_{2} \mathrm{TiO}_{4}$ phase. The peaks however, match with the theoretical positions for the wurtzite phase of $\mathrm{ZnO}$ (indicated by the red vertical lines in Fig. 3). Therefore, it can be concluded that a high temperature of at least $600{ }^{\circ} \mathrm{C}$ is essential for the formation of $\mathrm{Zn}_{2} \mathrm{TiO}_{4}$ phase, in addition to the correct composition of the sol. This finding is in good agreement with the formation behavior of $\mathrm{Zn}_{2} \mathrm{TiO}_{4}$ phase, as established by Dulin and Rase via the melt-mixing method. ${ }^{27}$

\section{Film composition}

Energy dispersive X-ray spectroscopy (EDX) is performed on the samples synthesized from the sol with molar concentration of $\mathrm{Zn}\left(\mathrm{CH}_{3} \mathrm{COO}\right)_{2} \cdot 2 \mathrm{H}_{2}: \mathrm{Ti}\left(\mathrm{O}_{2} \mathrm{C}_{2} \mathrm{H}_{4}\right)_{2}=1.05: 1$. The spray-deposited films are again calcined at 400 and $600{ }^{\circ} \mathrm{C}$. The EDX spectra of the films are shown in Fig. 4(a) and (b).

It is observed from the spectra that characteristic peaks of $\mathrm{Ti}$, $\mathrm{Zn}$ and $\mathrm{O}$ are available for both samples. In addition, a strong $\mathrm{Si}$ peak contributed by the substrate is also present. This is a substantial evidence of the purity of the sample because other elements could not be detected. The composition of both samples obtained in terms of atomic percent is listed in Table 1. It is clearly stated from the results that a calcination temperature of $600{ }^{\circ} \mathrm{C}$ is essential in order to produce $\mathrm{Zn}_{2} \mathrm{TiO}_{4}$ as for this particular sample, the atomic \% of $\mathrm{Zn}$ is nearly twice of that of $\mathrm{Ti}$, which matches with the stoichiometric composition of the compound. 

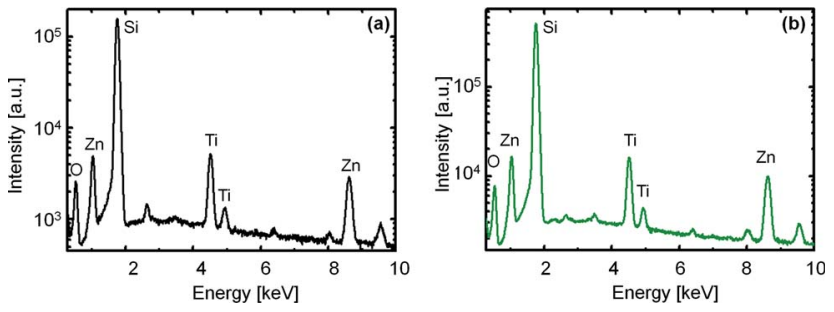

Fig. 4 EDX spectra obtained for spray-deposited films with molar concentration of $\mathrm{Zn}\left(\mathrm{CH}_{3} \mathrm{COO}\right)_{2} \cdot 2 \mathrm{H}_{2} \mathrm{O}: \mathrm{Ti}\left(\mathrm{O}_{2} \mathrm{C}_{2} \mathrm{H}_{4}\right)_{2}=1.05: 1$ after calcination at $400{ }^{\circ} \mathrm{C}$ (a) and $600{ }^{\circ} \mathrm{C}$ (b).

Table 1 Atomic composition of the spray-deposited films obtained from sol with molar concentration of $\mathrm{Zn}\left(\mathrm{CH}_{3} \mathrm{COO}\right)_{2} \cdot 2 \mathrm{H}_{2} \mathrm{O}$ : $\mathrm{Ti}\left(\mathrm{O}_{2} \mathrm{C}_{2} \mathrm{H}_{4}\right)_{2}=1.05: 1$, calcined at $400{ }^{\circ} \mathrm{C}$ and $600{ }^{\circ} \mathrm{C}$

\begin{tabular}{lll}
\hline Elements & Atomic $\%\left(400{ }^{\circ} \mathrm{C}\right)$ & Atomic $\%\left(600{ }^{\circ} \mathrm{C}\right)$ \\
\hline $\mathrm{Zn}$ & $36.91 \pm 0.77$ & $40.40 \pm 0.44$ \\
$\mathrm{Ti}$ & $22.02 \pm 0.25$ & $20.79 \pm 0.14$ \\
$\mathrm{O}$ & $41.07 \pm 0.26$ & $38.81 \pm 0.14$
\end{tabular}

\section{Optical properties}

The optical properties of the $\mathrm{Zn}_{2} \mathrm{TiO}_{4}$ calcined (at $600{ }^{\circ} \mathrm{C}$ ) film are tested by UV/vis spectroscopy. The absorbance data plotted in Fig. 5(a) shows that $\mathrm{Zn}_{2} \mathrm{TiO}_{4}$ also absorbs in the UV region like $\mathrm{TiO}_{2}$ and $\mathrm{ZnO}$. In the literature, different band gaps for this compound have been recorded depending on the synthesis route, composition and theoretical techniques such as density functional theory used for the calculation of the same..$^{17,28-30}$ In order to evaluate the band gap of the sample, Tauc's equation for direct band gap semiconductors ${ }^{31}$ is used as shown in eqn (2):

$$
(\alpha E)^{2}=A\left(E-E_{\mathrm{g}}\right)
$$

where $\alpha$ is the absorption coefficient, $E$ the incident photon energy, $A$ is a constant and $E_{\mathrm{g}}$ the band gap energy. The corresponding Tauc plot for $\mathrm{Zn}_{2} \mathrm{TiO}_{4}$ foam-like film is shown in Fig. 5(b) giving a band gap energy, $E_{\mathrm{g}}$ of $4.01 \mathrm{eV}$ which is within

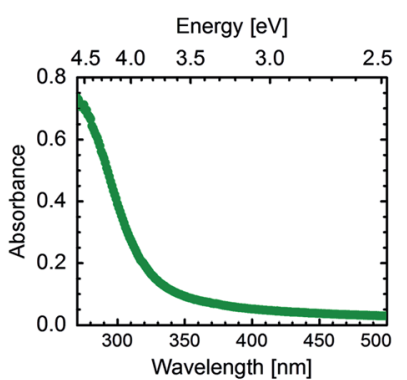

(a)

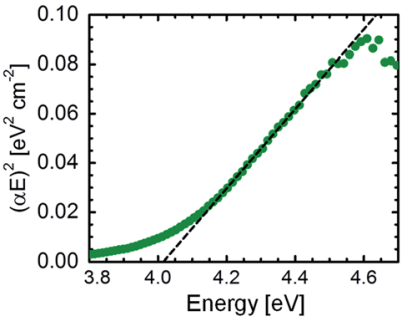

(b)
Fig. 5 (a) Absorbance spectrum of the calcined zinc orthotitanate film. (b) The corresponding Tauc plot of the same film in order to determine the band gap of the material present in the film, by linear extrapolation of the data to the energy axis.

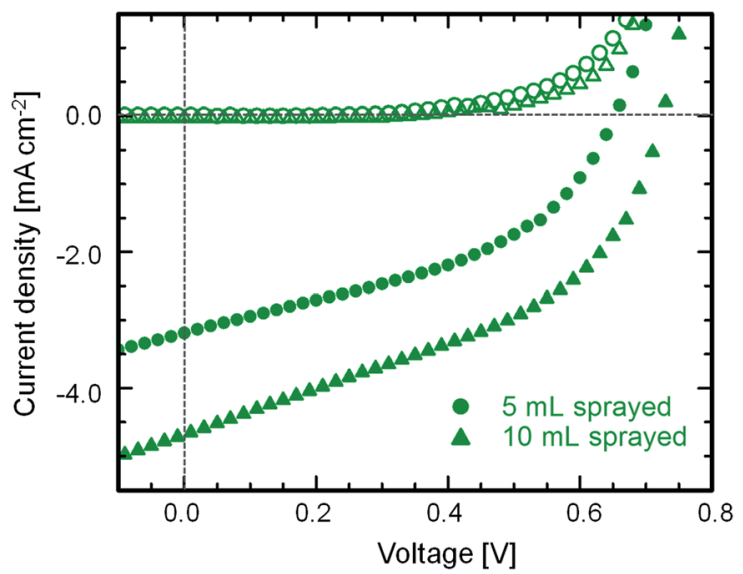

Fig. 6 Current density-voltage characteristics of dye-sensitized solar cells in dark (open circles) and under illumination (closed circles), prepared from spray-deposited zinc orthotitanate films. Different amount of zinc orthotitanate sol are sprayed: $5 \mathrm{~mL}$ and $10 \mathrm{~mL}$, as indicated.

the estimated range as listed in literature for crystalline $\mathrm{Zn}_{2} \mathrm{TiO}_{4}$ phase. $^{32,33}$

\section{Solar cell performance}

Using the optimized foam-like film morphology produced by spray deposition technique, preliminary tests have been performed with two different thicknesses of 4 and $10 \mu \mathrm{m}$ of the active layer for the DSSC (details about the device assembly are given in Section $\mathrm{S} 3 \dagger$ ). The fabricated DSSC is measured under AM1.5 solar spectrum conditions providing a light intensity set to $1000 \mathrm{~W} \mathrm{~m}^{-2}$. The typical current density-voltage plots for the solar cells are shown in Fig. 6 . The results from current-voltage characterization of active layers having different thicknesses are listed in Table 2. The increase in the short-circuit current density and open-circuit voltage with increasing film thickness of the active layer is clearly visible from the $J-V$ curves. This can be related to extra charge carrier pathways generated in the system with increasing amount of material. On the other hand, the increase in the fill factor is really minor. The power conversion efficiency of $1.5 \%$ is however very promising as a preliminary result and is the best announced so far with $\mathrm{Zn}_{2} \mathrm{TiO}_{4}$ films synthesized via sol-gel technique. As a comparison, the device efficiency is comparable to that obtained for DSSCs fabricated from $\mathrm{ZnO}$ nanowires as the electron-

Table 2 Current-voltage characteristics of DSSCs obtained by spraying different amounts of $\mathrm{Zn}_{2} \mathrm{TiO}_{4}$ sol as the active layer

\begin{tabular}{lllll}
\hline $\begin{array}{l}\text { Amount of sol } \\
\text { sprayed } \\
{[\mathrm{mL}]}\end{array}$ & $\begin{array}{l}J_{\mathrm{SC}}{ }^{a} \\
{\left[\mathrm{~mA} \mathrm{~cm}^{-2}\right]}\end{array}$ & $\begin{array}{l}V_{\mathrm{OC}}{ }^{b} \\
{[\mathrm{mV}]}\end{array}$ & $\begin{array}{l}\mathrm{FF}^{c} \\
{[\%]}\end{array}$ & $\begin{array}{l}\text { Power } \\
\text { conversion } \\
\text { efficiency [\%] }\end{array}$ \\
\hline 5 & 3.1 & 653 & 43.1 & 0.9 \\
10 & 4.6 & 724 & 43.6 & 1.5
\end{tabular}

${ }^{a}$ Short-circuit current density. ${ }^{b}$ Open-circuit voltage. ${ }^{c}$ Fill factor. 
conducting layer. ${ }^{34}$ Although optimizing the device efficiency was not the main focus in the present study, we believe, with certain modifications in the device fabrication protocol, such as incorporation of a blocking layer and a scattering layer ${ }^{5}$ will largely enhance the overall device performance and will be addressed in future work.

\section{Conclusions}

In summary, a suitable solution-based approach is shown to successfully synthesize pure $\mathrm{Zn}_{2} \mathrm{TiO}_{4}$ phase. In addition, the so called sol-gel route is used in combination with a structuredirecting diblock copolymer which allows for modifying and tuning the morphology and length scale of the nanostructures produced. The key to obtain a pure composite phase is therefore, individual synthesis of $\mathrm{TiO}_{2}$ and $\mathrm{ZnO}$ nanostructures followed by mixing them in a specific volume ratio rather than simultaneous synthesis of the $\mathrm{Zn}_{2} \mathrm{TiO}_{4}$ nanocomposite. Based on spray deposition method, homogeneous $\mathrm{Zn}_{2} \mathrm{TiO}_{4}$ films have been synthesized for applications in DSSCs. The requirement for high surface area of the active layer for intensified dye adsorption for applications in $\operatorname{DSSCs}^{35}$ is met by synthesizing the sponge-like network morphology of the film. Spray deposition is also shown to allow for an upscaling in the film thickness and thereby improving the final device performance. To the best of our knowledge, $\mathrm{Zn}_{2} \mathrm{TiO}_{4}$ DSSCs are reported for the first time in this article showing reasonable preliminary device performances. Hence, the present research sets a new landmark in the area of inorganic metal oxides and their compounds which have been increasingly sought for to develop new functional nanoscale devices. We postulate improvement in power conversion efficiency of $\mathrm{Zn}_{2} \mathrm{TiO}_{4}$ based DSSCs in near future with more optimized device fabrication procedure. Hence, the development of $\mathrm{Zn}_{2} \mathrm{TiO}_{4}$ as a new functional material parallel to conventional inorganic metal oxides in large-scale electrooptical applications is foreseen.

\section{Acknowledgements}

P. Weiser and A. Holleitner are gratefully acknowledged for the possibility to perform SEM measurements. The authors are also thankful to K. Helm-Knapp and S. Geprägs for EDX measurements. This work was supported by TUM.solar in the frame of the Bavarian Collaborative Research Project "Solar technologies go Hybrid" (SolTec).

\section{Notes and references}

1 S. Chen, W. Xing, J. Duan, X. Hu and S. Z. Qiao, J. Mater. Chem. A, 2013, 1, 2941.

2 Y.-J. Chang, E.-H. Kong, Y.-C. Park and H. M. Jang, J. Mater. Chem. A, 2013, 1, 9707.

3 N. T. Nolan, M. K. Seery and S. C. Pillai, Chem. Mater., 2011, 23, 1496.

4 Q. Xu, M. Järn, M. Lindén and J.-H. Smått, Thin Solid Films, 2013, 531, 222.
5 X. Miao, K. Pan, Y. Liao, W. Zhou, Q. Pan, G. Tian and G. Wang, J. Mater. Chem. A, 2013, 1, 9853.

6 D. Fu, X. L. Zhang, R. L. Barber and U. Bach, Adv. Mater., 2010, 22, 4270.

7 J. Burschka, N. Pellet, S.-J. Moon, R. Humphry-Baker, P. Gao, M. K. Nazeeruddin and M. Grätzel, Nature, 2013, 499, 316.

8 Q. Zhang, C. S. Dandeneau, X. Zhou and G. Cao, Adv. Mater., 2009, 21, 4087.

9 F. Zhuge, J. Qiu, X. Gao, X. Gan and W. Yu, Adv. Mater., 2011, 23, 1330.

10 J. A. Anta, E. Guillén and R. Tena-Zaera, J. Phys. Chem. C, 2012, 116, 11413.

11 Z.-X. Chen, J. van der Eyden, W. Koot, R. van den Berg, J. van Mechelen and A. Derking, J. Am. Ceram. Soc., 1995, 17, 2993.

12 G. Akgül, J. Mol. Struct., 2013, 1037, 35.

13 S. K. Manik, P. Bose and S. K. Pradhan, Mater. Chem. Phys., 2003, 82, 837.

14 Z. Cai, J. Song, J. Li, F. Zhao, X. Luo and X. Tang, J. Sol-Gel Sci. Technol., 2012, 61, 49.

15 Y. Yang, X. W. Sun, B. K. Tay, J. X. Wang, Z. L. Dong and H. M. Fan, Adv. Mater., 2007, 19, 1839.

16 Z. Hong, M. Wei, Q. Deng, X. Ding, L. Jiang and K. Wei, Chem. Commun., 2010, 46, 740.

17 Y.-S. Chang, Y.-H. Chang, I.-G. Chen, G.-J. Chen and Y.-L. Chai, J. Cryst. Growth, 2002, 243, 319.

18 Y.-J. Cheng and J. S. Gutmann, J. Am. Chem. Soc., 2006, 128, 4658.

19 K. Sarkar, M. Rawolle, E. M. Herzig, W. Wang, A. Buffet, S. V. Roth and P. Müller-Buschbaum, ChemSusChem, 2013, 6, 1414.

20 A. Abdellah, K. S. Virdi, R. Meier, M. Döblinger, P. MüllerBuschbaum, C. Scheu, P. Lugli and G. Scarpa, Adv. Funct. Mater., 2010, 22, 4078.

21 R. Rossmanith, C. K. Weiss, J. Geserick, U. Hörmann, N. Hüsing, U. Kaiser and K. Landfester, Chem. Mater., 2008, 20, 5768.

22 X. Jiang, T. Herricks and Y. Xia, Adv.Mater., 2003, 15, 1205.

23 J. Perlich, G. Kaune, M. Memesa, J. S. Gutmann and P. Müller-Buschbaum, Philos. Trans. R. Soc., A, 2009, 367, 1783.

24 A. Sacco, A. Lamberti, R. Gazia, S. Bianco, D. Manfredi, N. Shahzad, F. Cappelluti, S. Ma and E. Tresso, Phys. Chem. Chem. Phys., 2012, 14, 16203.

25 K. Sarkar, M. Rawolle, M. A. Niedermeier, W. Wang, E. M. Herzig, V. Körstgens, A. Buffet, S. V. Roth and P. Müller-Buschbaum, J. Appl. Crystallogr., 2014, 47, 76.

26 K. Hayat, M. A. Gondal, M. M. Khaled, S. Ahmed and A. M. Shemsi, Appl. Catal., A, 2010, 12920.

27 F. H. Dulin and D. E. Rase, J. Am. Ceram. Soc., 1960, 43, 125. 28 J. C. Conesa, Catal. Today, 2013, 208, 11.

29 S. A. Mayén-Hernández, G. Torres-Delgado, R. CastanedoPérez, M. G. Villarreal, A. Cruz-Orea, J. G. M. Alvarez and O. Zelaya-Angel, J. Mater. Sci.: Mater. Electron., 2007, 18, 1127.

30 C. Wang, B.-Q. Xu, X. Wang and J. Zhao, J. Solid State Electrochem., 2005, 178, 3500. 
31 J. Tauc, R. Grigorovici and A. Vancu, Phys. Status Solidi, 1966, 15, 627.

32 S. A. Mayén-Hernández, G. Torres-Delgado, R. CastanedoPérez, M. G. Villarreal, A. Cruz-Orea, J. G. M. Alvarez and O. Zelaya-Angel, J. Mater. Sci.: Mater. Electron., 2007, 18, 1127.
33 C. Wang, B.-Q. Xu, X. Wang and J. Zhao, J. Solid State Chem., 2005, 178, 3500.

34 Q. Zhang, C. S. Dandeneau, X. Zhou and G. Cao, Adv. Mater., 2009, 21, 4087.

35 I. Gonzalez-Valls and M. Lira-Cantu, Proc. SPIE, 2012, 8471, $84710 \mathrm{X}$. 